\title{
1. Introduction: constitutional pluralism as inequality and the asymmetry of the EMU
}

\subsection{INTRODUCTION}

\subsubsection{Introducing the Two Themes of the Book}

Who would have thought that the German Federal Constitutional Court (Bundesverfassungsgericht) would eventually declare an act by the European Union as ultra vires and order the German Federal Government and Federal Parliament to act in order to redress this state of affairs. This is exactly what the German court did in its ruling on 5 May 2020 in a case concerning the European Central Bank's (ECB) Public Sector Purchase Programme (PSPP). ${ }^{1}$ This was despite the fact that the Court of Justice of the European Union (CJEU) had already concluded in Weiss that the PSPP was within the ECB's mandate. ${ }^{2}$ This case represents a culmination of a long process and serves as the best example to introduce the topic of this book.

In the early 2010s the Eurozone faced an economic crisis that then evolved into a political and constitutional crisis. As a result of this crisis, the EU and the Member States adopted a host of legal measures that aimed to combat the crisis and to prevent future crises. From a constitutional perspective, the measures were both novel and controversial. They changed the nature and functioning of the Economic and Monetary Union (EMU) and had severe consequences for both Member States and citizens alike. Thus, it was not surprising that the measures generated a wealth of case law concerning their legality under both EU law and national law.

Such cases - just like the above-mentioned recent ruling by the German Federal Constitutional Court - are expressions of clashes between national constitutions and the EU's constitutional order as effectuated by courts acting as the guardians of the very constitutions establishing their competences. Since

2 BvR 859/15, 05 May 2020 (PSPP judgment).

C-493/17 Weiss EU:C:2018:1000. 
the adoption of the Treaty of Maastricht and the inception of the EMU, the role of courts as central participants in the European multi-level constitutional and political discourse has increased considerably. This is mainly due to a phenomenon called constitutional pluralism; namely, the fact that the national constitutions and the EU's constitutional norms are both in force in the Member States yet without a settled hierarchy between the two. Since the 1990s, constitutional pluralism has become the central theory of European constitutionalism that is used to describe the current constitutional constellation, but also, at least by some, to argue for the normative acceptance of the current constellation.

The euro crisis and constitutional pluralism seem to have been the dominant themes within EU constitutional law scholarship during the past decade. In fact, one could argue that the euro crisis has been the main substantive topic whereas the main theoretical premise has been offered by constitutional pluralism. A substantial amount of literature has been written within both broad fields.

The literature on the constitutional aspects of the euro crisis has focused on how the reactions to the crisis have affected the dynamics of political decision-making within the $\mathrm{EU}^{3}{ }^{3}$ and what the adopted mechanisms mean in light of political and legal accountability. ${ }^{4} \mathrm{~A}$ central conclusion has been that despite no formal amendments to the EU Treaties, the fundamental principles underlying the EMU have been transformed. ${ }^{5}$ This transformation has centred around the objective of securing financial stability within the Eurozone ${ }^{6}$ and is visible in most of the legal mechanisms adopted pursuant to the crisis. ${ }^{7}$ Furthermore, constitutional analysis has focused on how the various economic and political assumptions on which the EMU has been established have contributed to the crisis ${ }^{8}$ and how this constitutional framework seems paradoxical

\footnotetext{
3 A. Hinarejos, The Euro Area Crisis in Constitutional Perspective (Oxford University Press 2015).

4 M. Markakis, Accountability in the Economic and Monetary Union: Foundations, Policy, and Governance (Oxford University Press 2020).

5 K. Tuori and K. Tuori, The Eurozone Crisis: A Constitutional Analysis (Cambridge University Press 2014).

6 V. Borger, The Currency of Solidarity: Constitutional Transformation during the Euro Crisis (Cambridge University Press 2020).

$7 \quad$ G. Lo Schiavo, The Role of Financial Stability in EU Law and Policy (Wolters Kluwer 2017).

8 D. Adamski, Redefining European Economic Integration (Cambridge University Press 2018).
} 
when compared to the federal system of the USA. ${ }^{9}$ Moreover, the effects that the measures have had at the national level have been closely documented. ${ }^{10}$

The theory of constitutional pluralism has attracted attention from most scholars working with European constitutionalism, as is visible in the number of edited compilations on the topic, ${ }^{11}$ although book-length treatments on it are still scarce. Some have used constitutional pluralism as a descriptive and conceptual starting point for broader theoretical discussions on European constitutionalism. ${ }^{12}$ Several scholars have argued that constitutional pluralism offers the key to solving some of the persistent problems in the EU's constitutional design. These have included, for example, a substantive version of pluralism building on constitutional dialectics ${ }^{13}$ and arguing against the constitutionalisation of post-national law, opting instead for a pluralist vision. ${ }^{14}$ Broadening the scope from the EU's internal constitutional discussion to its relations with transnational actors, a theory of principled legal pluralism has been proposed as the way to understand and develop the EU's constitutional order. ${ }^{15}$ Furthermore, attention has also been paid to the plurality of socio-economic ideologies found in the EU Treaties. ${ }^{16}$

However, the euro crisis and constitutional pluralism have seldom been studied together. The events and consequences of the crisis have not been analysed within the framework of constitutional pluralism, nor has the theory of constitutional pluralism been reconfigured as a response to the events of the euro crisis. Notable exceptions seem to be the work of Goldmann and Kelemen, who represent opposite ends in the debate. Based on the exchange between the CJEU and the German Federal Constitutional Court in Gauweiler, ${ }^{17}$ Goldmann

9 F. Fabbrini, Economic Governance in Europe: Comparative Paradoxes and Constitutional Challenges (Oxford University Press 2016).

10 See e.g. M. Adams, F. Fabbrini and P. Larouche (eds), The Constitutionalization of European Budgetary Constraints (Hart Publishing 2014); T. Beukers, B. de Witte and C. Kilpatrick (eds), Constitutional Change through Euro-Crisis Law (Cambridge University Press 2017).

11 See e.g. M. Avbelj and J. Komárek (eds), Constitutional Pluralism in the European Union and Beyond (Hart Publishing 2012); G. Davies and M. Avbelj (eds), Research Handbook on Legal Pluralism and EU Law (Edward Elgar Publishing 2018).

12 K. Tuori, European Constitutionalism (Cambridge University Press 2015).

13 K. Jaklič, Constitutional Pluralism in the EU (Oxford University Press 2014).

14 N. Krisch, Beyond Constitutionalism: The Pluralist Structure of Postnational Law (Oxford University Press 2010).

15 M. Avbelj, The European Union under Transnational Law: A Pluralist Appraisal (Hart Publishing 2018).

16 C. Kaupa, The Pluralist Character of the European Economic Constitution (Hart Publishing 2016).

17 C-62/14 Gauweiler EU:C:2015:400; 2 BvR 2728/13, 21 June 2016 (OMT final judgment). 
has argued that such reactions by national constitutional courts result in 'mutually assured discretion', meaning that the imminent conflict between the national courts and the CJEU is kept at bay by the somewhat relative vagueness of the CJEU's rationality and proportionality checks. ${ }^{18}$ Kelemen, on the other hand, has argued that such cases bring to the fore the unsustainability of constitutional pluralism as the issue of Kompetenz-Kompetenz remains to be settled. ${ }^{19}$ Avbelj has used the euro crisis as one example when developing his theory of principle legal pluralism; however, the objective of this theory is not the relationship between the EU and the Member States but rather that between the EU and the wider world. ${ }^{20}$ Similarly, Fichera has also used the euro crisis as an example whilst developing his argument of security as the meta-rational of European integration, which he contrasts with the theory of constitutional pluralism, but his main focus is not on the euro crisis and constitutional pluralism. ${ }^{21}$ The aforementioned scholarship represent the most novel accounts in further developing the theory of constitutional pluralism, but their scope and main argument differ from the one presented in this book.

This distinguished shortcoming in the pluralist literature is interesting for at least two reasons. First, the theoretical study of EU law has long been criticised for being reactive and event-driven, and thus only capable of 'middle-range theorizing'. ${ }^{22}$ However, although the discussion on constitutional pluralism is in no way novel - it was sparked by the German Federal Constitutional Court's judgments as early as the $1990 \mathrm{~s}^{23}$ - it seems that the events of the euro crisis have not given rise to a re-evaluation of the leading theory of European constitutionalism. Should one thus conclude that theory building has not met

18 M. Goldmann, 'Constitutional Pluralism as Mutually Assured Discretion: The Court of Justice, the German Federal Constitutional Court, and the ECB' (2016) Maastricht Journal of European and Comparative Law 23(1), 119-35; M. Goldmann, 'Discretion, Not Rules: Postunitary Constitutional Pluralism in the Economic and Monetary Union' in G. Davies and M. Avbelj (eds), Research Handbook on Legal Pluralism and EU Law (Edward Elgar Publishing 2018).

19 R. D. Kelemen, 'On the Unsustainability of Constitutional Pluralism: European Supremacy and the Survival of the Eurozone' (2016) Maastricht Journal of European and Comparative Law 23(1), 136-50; R. D. Kelemen, 'The Dangers of Constitutional Pluralism' in G. Davies and M. Avbelj (eds), Research Handbook on Legal Pluralism and EU Law (Edward Elgar Publishing 2018).

$20 \quad$ Avbelj (n 15), pp. 88-98.

${ }_{21}$ M. Fichera, The Foundations of the EU as a Polity (Edward Elgar Publishing 2018), Chapter 4.

22 See N. Walker, 'Legal Theory and the European Union: A 25th Anniversary Essay' (2005) Oxford Journal of Legal Studies 25(4), 581-601.

${ }_{23}$ See J. Baquero Cruz, 'The Legacy of the Maastricht-Urteil and the Pluralist Movement' (2008) European Law Journal 14(4), 389-422. 
polity building? ${ }^{24}$ Still, there are good reasons for concluding that 'constitutional theory must always be about constitutional practice', ${ }^{25}$ or otherwise it is useless. ${ }^{26}$ This leads to the second reason, which is practical: the normative attractiveness and validity of the theory of constitutional pluralism is deeply questioned by the German Federal Constitutional Court's PSPP judgment.

If constitutional pluralism is the defining theoretical discussion on European constitutionalism, and if the euro crisis has been the main substantive topic recently - amounting to an 'existential crisis' for the $\mathrm{EU}^{27}$ - then combining these two is highly relevant and as such offers the perfect laboratory for an analysis of the current state of European constitutionalism. This book sets out to do just that.

The argument put forth in this book is rather simple, but it goes to the very heart of European constitutionalism: differences in the Member States' constitutional orders result in their constitutional courts, or other institutions with similar constitutional review functions, being able to affect the EU's political process to varying degrees. It is the national constitutional orders as such - not EU law or the size and relative political importance of the Member State - that dictates their ability to interact with the CJEU and to affect the European-level political process. These differences mean that some national courts are in a privileged position vis-à-vis other courts when it comes to their ability to influence the course of European integration. Thus, by definition, the rest are in an unequal position. This is called the inequality thesis.

Although the inequality thesis begins as a merely descriptive argument, when connected to larger underlying debates it also gathers normative force and academic significance. As is evident, relations between national courts and EU law also have political implications. The privileged courts can essentially end up hijacking the European-level political process, while the disadvantaged courts face the ungrateful task of finding a way to accommodate their constitutional orders to the chosen path. This questions the legitimacy of such interventions into the European-level political process by national constitutional courts - and thus constitutional pluralism's capacity as a normative theory of European constitutionalism. A normative theory of European constitutional-

24 See J. Shaw, 'The European Union - Discipline Building Meets Polity Building' in P. Cane and M. Tushnet (eds), The Oxford Handbook of Legal Studies (Oxford University Press 2003).

25 R. Schütze, From Dual to Cooperative Federalism: The Changing Structure of European Law (Oxford University Press 2013), p. x.

${ }_{26}$ See R. van Gestel and H.-W. Micklitz, 'Why Methods Matter in European Legal Scholarship' (2014) European Law Journal 20(3), 292-316, p. 300.

27 See A. J. Menéndez, 'The Existential Crisis of the European Union' (2013) German Law Journal 14(5), 453-526. 
ism ought to tell us how conflicts between national law and EU law should be settled and what the constitutional relationship between the two respective constitutional orders should be like.

In a constitutional order comprising over 20 sovereign states, such confrontations and inequality seem inevitable. The plurality of interacting constitutions makes such confrontations unavoidable. This is true the more intricate and far-reaching the symbiosis between these constitutions becomes due to European integration being continually deepened. Constitutional pluralists argue that such plurality and the ensuing confrontations are actually beneficial for the whole constitutional constellation, since interaction necessitates taking into consideration the other and finding the best means of conciliation through dialogue.

This book argues the opposite: constitutional pluralism is not a valid normative theory of European constitutionalism. The EU's current constitutional order is undoubtedly beset by plurality, but an appraisal of pluralism cannot be based on this. On the contrary, observing constitutional practice points to just the opposite. Stricter adherence to the prescribed constitutional roles and functions is needed. In fact, from the perspective of the EU Treaties, this issue is clear, as EU law has primacy over national law and the CJEU is the ultimate arbiter of constitutional conflicts - what creates the problems are the national courts that contest this.

\subsubsection{Research Questions and the Argument of the Book}

The primary purpose of this book is to assess the theory of constitutional pluralism, especially the claim that the national judicial review of EU law somehow induces legitimacy into the EU's constitutional order and is therefore inherently beneficial. ${ }^{28}$ This assessment is done by utilising the events of the euro crisis as a case study. This analysis focuses on how national courts and the CJEU reviewed the various legal measures enacted as a response to the crisis. While the substance of the studied legal mechanisms concerns the EMU, this is a legal study on European constitutionalism. Thus, the various economic reasons and explanations relating to the crisis and the functioning of the EMU in general are only discussed to the extent necessary for appreciating the studied legal events.

28 The terms 'judicial review' and 'constitutional review' are used interchangeably in this study, although historically they have a different meaning. Alternatively, what this study focuses on could be called 'judicial constitutional review', that is the review of political and legislative decisions against the constitution by a judicial organ, a court. See R. Grote, 'Judicial Review' in Max Planck Encyclopedia of Comparative Constitutional Law (Oxford University Press Online). 
The primary interest of this study is in the constitutional practice that amounts to the phenomenon called constitutional pluralism. How did the national courts and the CJEU participate in the European-level political process during the euro crisis? What effects did this have? Answering such descriptive questions results in the thesis that constitutional pluralism is not an adequate normative theory of European constitutionalism because of the problems that the eminent plurality creates. This is, in essence, the inequality thesis.

The secondary interest of this study is in the asymmetrical structure of the EMU and the consequences it has for European constitutionalism. How did the asymmetrical structure of the EMU affect the formation and adoption of the crisis response measures? What consequences did this have on European constitutionalism? Answering such descriptive questions results in the thesis that the EMU's asymmetrical structure is unsustainable. The asymmetrical structure is the primary substantive reason for why national courts contested the crisis response measures and why the rulings of the CJEU in cases such as Gauweiler are open to criticism from a constitutional perspective.

Although both theses express a strong resentment against the current constitutional structure of EU Treaties, the purpose of this study is not to engage in the debate on the future constitutional and political nature of the EU. In this respect, this study does not ask questions such as: What is the best or preferable constitutional structure for the European Union? Answering this type of a question would require creating some sort of a blueprint for a federal Europe, which would broaden the scope of this study too much. Although politicians and academics have made various proposals to this effect, ${ }^{29}$ these will be left unaddressed in this study notwithstanding a few general remarks in the final conclusions.

What type of argument is the inequality thesis? What does this book actually argue? The inequality thesis begins as a descriptive account that can be assessed through three factors. ${ }^{30}$ The first factor is at which stage of the European-level political process a national court can participate. Chronological reconstructions of the events of the euro crisis are used to assess this aspect. The crucial point here is the distinction to courts that have delivered their ruling at such a point of the political process that their ruling has had the possibility to affect the outcome of politics at the European level, and to courts that have delivered their ruling at a later point in time and have thus only had the possibility to affect domestic politics. A closer look at the individual judgments reveals

29 See e.g. Fabbrini (n 9), Chapters 4-6; Hinarejos (n 3), Chapters 9-10; Tuori and Tuori (n 5), Chapter 8; Markakis (n 4), Chapter 9.

30 See T. Tuominen, 'Aspects of Constitutional Pluralism in Light of the Gauweiler Saga' (2018) European Law Review 43(2), 186-204, pp. 190-94. 
that - prior to the German Federal Constitutional Court's PSPP judgment no national court rejected any of the crisis response measures adopted. This indicates that the courts acting at a later stage of the political process faced a predicament to accept the European measures at whatever cost. Simply put, if a national court can no longer alter the course of European politics, it faces strong political pressure to deem the measure as constitutional. It needs to be stressed that this first aspect is not about whether national courts actually did affect the content of the European-level politics, but rather whether they had the possibility to do so. This does not, however, mean that decisions given at a later stage of the political process would be meaningless altogether. Indeed, as has been pointed out by previous research, such judgments can affect the course of politics later on through a process called autolimitation. ${ }^{31}$ This effect is also observed in the case studies, but it is a different type of effect as the one described here.

The second factor is how a national court can interact with the CJEU or European-level politics. This refers to the jurisdiction and the rules of procedure of national courts, which define how they can review EU law or send preliminary references to the CJEU. Vast differences exist between the national institutions charged with constitutional review in the Member States. ${ }^{32}$ In particular, the jurisdiction of the German Federal Constitutional Court has been seen to enable the intense juridification of politics, as it enables politicians and individual citizens to subject political decisions to review by the Federal Constitutional Court in an abstract manner. ${ }^{33}$ Here, the point is that due to differences in national constitutions, some courts are better placed to interact with the CJEU. The Federal Constitutional Court especially stands out.

The third and final factor is why national courts want to review EU law, i.e., what are the substantive issues (i.e. rights) in their constitutions that they claim to protect by such a review. As the content of the Member States' constitutions differs, it is understandable that national courts, acting as the guardians of these constitutions, pay attention to different aspects of EU law. This raises the question of whether the legality of EU law should be assessed in light of the EU's own 'constitution', the EU Treaties, or in light of the different and differing national constitutions. It seems logical to favour the first, since that is the only way that the primacy, unity and effectiveness of EU law can be

31 See A. Stone Sweet, Governing with Judges. Constitutional Politics in Europe (Oxford University Press 2000), p.75.

32 See M. de Visser, Constitutional Review in Europe: A Comparative Analysis (Hart Publishing 2014).

33 See M. Shapiro and A. Stone Sweet, On Law, Politics, and Judicialization (Oxford University Press 2002), p. 368. 
guaranteed..$^{34}$ Moreover, there are mechanisms in the EU Treaties - namely Articles 4(2) and 6(3) TEU - that facilitate taking into consideration diverging national interests.

These descriptive accounts lead to a normative question, namely whether review by national courts is actually able to induce legitimacy into the EU's constitutional order. Traditionally, judicial review is seen to increase the legitimacy of government actions, as it allows the checking of political decisions against the constitution, which embodies higher objectives, principles and rights, particularly fundamental rights. ${ }^{35}$ The legitimacy of judicial review is usually questioned by asking why countermajoritarian institutions such as courts should be given the possibility to overrule decisions made by democratically accountable institutions. ${ }^{36}$ The purpose of the inequality thesis is not to engage with this traditional debate; rather, the inequality thesis gives this debate a new twist by showing how, in a state of constitutional plurality, it is not a court and a legislator from the same constitutional system that are pitted against each other, but rather a single court from a group of courts (all Member States' courts) against the European legislator or political executive. Furthermore, in some instances it is not that a court is checking the decisions of a legislator, but that a court is pitted against other technocratic institutions, such as the German Federal Constitutional Court and the ECB in Gauweiler. ${ }^{37}$

Lastly, it needs to be stressed that the point of the inequality thesis is not to 'defeat' constitutional pluralism as a practice. Rather, the point is to show how constitutional plurality is not an optimal state of affairs, and therefore that one cannot derive a normative claim from it; in other words, that the 'ought' cannot be derived from the 'is'.

34 See C-399/11 Melloni EU:C:2013:107, para. 60.

35 See e.g. K. Tuori, Ratio and Voluntas: The Tension between Reason and Will in Law (Ashgate 2010), Chapter 8.

36 See R. Bellamy, Political Constitutionalism: A Republican Defence of the Constitutionality of Democracy (Cambridge University Press 2007); J. Waldron, 'The Core of the Case Against Judicial Review' (2006) Yale Law Journal 115(6), 1346-406. In the context of the European Union, see N. de Boer, 'The False Promise of Constitutional Pluralism' in Davies and Avbelj (n 11).

37 See M. Wilkinson, 'Economic Messianism and Constitutional Power in a "German Europe": All Courts are Equal, but Some Courts are More Equal than Others', LSE Law, Society and Economy Working Papers 26/2014 (2014), p. 25. 


\subsubsection{Selection of Case Studies and their Methodology}

This book contains four case studies on different legal mechanisms adopted as a reaction to the euro crisis. These mechanisms are:

- the Treaty on Stability, Coordination and Governance in the Economic and Monetary Union (the Fiscal Compact);

- the European Stability Mechanism (ESM);

- the European Banking Union;

- the European Central Bank's Outright Monetary Transactions programme (OMT programme).

The functioning of these four mechanisms is heavily interwoven. The common denominator is that they all aim to safeguard the financial stability of the euro area as a whole in one way or the other, and behind each of them we can observe the asymmetrical structure of the EMU. Their content and the EMU's legal framework will be briefly explained in the following section.

The studied mechanisms represent all of the four main types of reactions taken as a result of the euro crisis. In this sense the selection of case studies is all-encompassing. Furthermore, the selected cases represent three different regulatory approaches: international law-based measures (the Fiscal Compact and the ESM), EU secondary law measures (the Banking Union), and decisions by an EU institution (the OMT programme). For each of these three categories, the dynamics of how national courts and the CJEU participate in the European-level political process are different. Thus, this makes it possible to engage with both of the research questions of this study in a meaningful manner: the case studies enable assessment of both the suitability of constitutional pluralism as a normative theory of European constitutionalism and also the consequences of the asymmetrical structure of the EMU.

Fabbrini has argued that recourse to international law, namely the adoption of the Fiscal Compact and the ESM, was the main cause for the intense participation of national courts, as EU secondary law does not facilitate judicial review before national courts in a similar manner. He calls this the 'paradox of judicialization' ${ }^{38}$ While the case studies on the Fiscal Compact and the ESM corroborate Fabbrini's argument, the case studies on the Banking Union and the OMT programme further develop this line of argument. First, the case study on the Banking Union shows, conversely, how the use of EU secondary law meant that national courts did not have similar possibilities to participate. Second, the case study on the OMT programme highlights the fact that the national constitutions truly define how national courts can interact with the

\footnotetext{
38 See Fabbrini (n 9), Chapter 2.
} 
CJEU, as it is questionable whether Gauweiler could have originated from any other Member State than Germany.

As a caveat towards possible criticism concerning the delimitation of the case studies, one issue still needs to be addressed. Why is the vast array of national cases concerning the application of the austerity measures, incumbent due to accepting assistance from the ESM, not discussed at all? ${ }^{39}$ Indeed, several of such cases have reached the CJEU, ${ }^{40}$ and the austerity measures as such have posed relevant fundamental rights concerns. ${ }^{41}$ The reason for excluding such cases is simple: this study focuses on the adoption of the crisis response mechanisms, not their use. Including also the latter would broaden the scope of this study impracticably. However, it is conceded that from a substantive perspective, for example the Portuguese Constitutional Court's (Tribunal Constitucional) judgments on the implementation of austerity measures stemming from ESM assistance seem interesting. The court has overruled many such measures due to their breaching the national constitution, and whilst doing so the court has even invoked the principle of national constitutional identity and Article 4(2) TEU. ${ }^{42}$

All of the case studies contain a chronological reconstruction of the adoption of the respective mechanism. These reconstructions address issues that took place at both the national and the European levels. The reconstructions explain the main political and legal events relating to the adoption of the mechanisms. The purpose of these reconstructions is to show what types of events affected, could have affected, or did not affect the adoption of the four mechanisms. The national judgments mentioned in the reconstructions are not analysed from a comparative constitutional law perspective. This study does not aim to understand why national courts reached certain outcomes. The chosen perspective is European, with an attempt to understand the consequences of these cases for the European-level political process and EU law.

The flow of political events has been deduced from official materials such as decisions by the EU institutions, press releases and other documents. Research literature on the events of the crisis and contemporary newspaper articles have

39 On these cases, see e.g. Beukers, de Witte and Kilpatrick (n 10).

40 See e.g. joined cases C-8/15 P-C-10/15 P Ledra Advertising EU:C:2016:701; joined cases C-105/15 - C-109/15 P Mallis EU:C:2016:702; C-258/14 Florescu EU:C: 2017:448.

${ }^{41}$ See L. Ginsborg, 'The Impact of the Economic Crisis on Human Rights in Europe and the Accountability of International Institutions' (2017) Global Campus Human Rights Journal 1, 97-117.

42 See M. Canotilho, T. Violante and R. Lanceiro 'Austerity Measures Under Judicial Scrutiny: the Portuguese Constitutional Case-Law' (2015) European Constitutional Law Review 11(1), 155-83. 
been used as secondary sources. The discussed national judgments have been sourced from several comparative studies that have included national reports from the Member States. ${ }^{43}$ Research literature has been used as a secondary source in this aspect too.

Methodologically the reconstructions in the case studies draw inspiration from process tracing ${ }^{44}$ and historical institutionalism, a theory of comparative politics often used in the study of European integration. Historical institutionalism emphasises 'how institutions emerge from and are embedded in concrete temporal processes' ${ }^{45}$ What this means is that importance is accorded to temporality: 'the timing and sequence of events shape political processes'. More specifically, historical institutionalism purports that factors such as unpredictability, inflexibility, nonergodicity and inefficiencies shape the outcome of political processes. ${ }^{46}$ These might include, for example, how national constitutions set constraints for international action and how these constitutions are difficult to amend. ${ }^{47}$ While a purely institutionalist analysis might be revealing in that it carves out why and how the crisis mechanisms came to be ${ }^{48}$ from the perspective of EU constitutional law, such analyses seem to stop halfway. This study utilises some of the insights of historical institutionalism in that the possible causal relations between the different political and legal instances are paid special attention. As will be shown in the case studies, the above-mentioned factors of unpredictability, inflexibility, nonergodicity and

43 See U. Neergaard, C. Jacqueson and J. Hartig Danielsen (eds), The Economic and Monetary Union: Constitutional and Institutional Aspects of the Economic Governance within the EU. The XXVI FIDE Congress in Copenhagen, 2014 (DJOF Publishing 2014); G. Bándi, P. Darák, A. Halustyik and P. L. Láncos (eds), European Banking Union. Congress Proceedings Vol. 1. The XXVII FIDE Congress in Budapest, 2016(Wolters Kluwer 2016); the European University Institute's project Constitutional Change Through Euro Crisis Law, http://eurocrisislaw.eui.eu/ (accessed 1 September 2020).

${ }^{44}$ See F. Schimmelfennig, 'Efficient Process Tracing: Analyzing the Causal Mechanisms of European Integration' in A. Bennett and J. T. Checkel (eds), Process Tracing: From Metaphor to Analytical Tool (Cambridge University Press 2015).

45 See K. Thelen, 'Historical Institutionalism in Comparative Politics' (1999) Annual Review of Political Science 2(1), 369-404, p. 371.

46 O. Fioretos, 'Historical Institutionalism in International Relations' (2011) International Organization 65(2), 367-99, p. 371.

47 M. A. Pollack, 'The New Institutionalisms and European Integration' in A. Wiener and T. Diez (eds), European Integration Theory (Oxford University Press 2004), pp. 139-40.

${ }_{48}$ See e.g. L. Gocaj and S. Meunier, 'Time Will Tell: The EFSF, the ESM, and the Euro Crisis' (2013) Journal of European Integration 35(3), 239-53; A. Verdun, 'A Historical Institutionalist Explanation of the EU's Responses to the Euro Area Financial Crisis' (2015) Journal of European Public Policy 22(2), 219-37. 
inefficiencies all seem to be present in the formulation and uptake of the crisis response mechanisms.

The tripartite contextuality of economic-politic-law that is looming behind the substantive topic of this study leads to one further methodological preconception: while political scientists and economists usually posit that material interests are primarily in charge of shaping the behaviour of actors, lawyers are quick to point out that legal norms and the ideas underlying them also affect the decisions that different actors take. Dehousse and Weiler most famously explained this by stating that law is 'both the object and agent of integration' ${ }^{49}$ Thus, the four case studies also try to highlight the dialectic relationship between economic interests, political forces and legal frameworks. This is important with regards to both research questions. On one hand, the EU's legal framework seems to have affected the reactions taken to the euro crisis and the national legal frameworks on how national courts interacted with the EU's political process. On the other hand, political differences concerning economic and fiscal policies, as well as idiosyncratic interests particular to each Member States' economic situation and banking sector, seem to have affected which types of legal reactions they favoured.

\subsubsection{The Structure of the Book}

The rest of this introduction first introduces the relevant aspects of the legal framework of the EMU and its asymmetrical structure (section 1.2.1). Next, the reasons for the euro crisis and the events surrounding the crisis, as well as the legal mechanisms of each case study are briefly introduced (section 1.2.2). The section then ends in a discussion on how the asymmetry of the EMU and constitutional pluralism are linked (1.2.3). Lastly, the theory of constitutional pluralism is introduced (section 1.3).

Overall, the book proceeds as follows: Chapters 2-5 contain the four case studies. Each case study begins with a chronological reconstruction of the events leading up to the adoption of the respective legal mechanism and its consequent review by national courts and the CJEU. Then, the interplay between economic, political and legal factors in the adoption of the respective mechanism is briefly discussed. Lastly, the constitutional significance of the respective mechanism, mainly with regards to how it relates to the asymmetry of the EMU, is analysed.

Chapters 6-8 are devoted to the main argument of the book, the inequality thesis, and the critique of constitutional pluralism.

49 R. Dehousse and J. Weiler, 'The Legal Dimension' in W. Wallace (ed.), The Dynamics of European Integration (Pinter Publishers 1990), p. 243. 
Chapter 6 lays out the inequality thesis by explaining how differences in national legal frameworks allow for a varying degree of direct or indirect participation by national courts in the European-level political process. The chapter then addresses the problems that ensue from the fact that some national courts are in a privileged position vis-à-vis the others. It is argued that such inequality is problematic from both a political and a legal perspective. The national court's influence essentially usurps the Union's political process; in effect, they can even end up hijacking it. Legally speaking, the inequality of the national courts, or actually the dominant position of some, manifests itself in national courts questioning the interpretive Kompetenz-Kompetenz of the CJEU. Lastly, the chapter then turns to the normative basis of the inequality thesis: How according to Article 4(2) TEU, the 'Union shall respect the equality of Member States before the Treaties as well as their national identities, inherent in their fundamental structures, political and constitutional, inclusive of regional and local self-government'. The chapter presents a novel argument concerning the meaning of Article 4(2) TEU: The equality clause is there to guarantee horizontally the equality of the Member States vis-à-vis each other in relation to the EU, whereas the national identity clause is there to protect the Member States vertically from the EU.

Chapter 7 first focuses on the predicament that most of the national courts had when they reviewed the different legal mechanisms adopted pursuant to the crisis. It is argued that those national courts that were able to review the mechanisms at a later stage of the political and legal process, sometimes even after they had already entered into force, faced a strong predicament to find these measures in compliance with their national constitutions. Thus, review by these courts - as opposed to the privileged courts that were able to act early on and might have had an influence on the process - does not strengthen the legitimacy of the overhaul of the Union's economic governance regime either. Then, the chapter addresses the possibilities that the CJEU might have to address such inequality. Building on an analysis of Gauweiler, both a structural and a substantive alternative are presented. The first relates to whether the CJEU can affect the competences of national courts through its own doctrine, similar to what the outcome of the Simmenthal revolution was. ${ }^{50}$ The second is about what types of preliminary references the CJEU admits and how it answers them. Lastly, the chapter discusses the shortcomings of the substan-

50 Case 106/77 Simmenthal EU:C:1978:49. See D. Piqani, 'The Simmenthal Revolution Revisited: What Role for Constitutional Courts?' in B. de Witte, J. A. Mayoral, U. Jaremba, M. Wind and K. Podstawa (eds), National Courts and EU Law: New Issues, Theories and Methods (Edward Elgar Publishing 2016). 
tive alternative, which reveal the inadequacy of the EU's current constitutional constellation.

Chapter 8 addresses the idea of constitutional pluralism at a more conceptual and theoretical level. It first explores the different modalities of constitutional pluralism that can be identified through the case studies. The chapter then discusses whether constitutional pluralism is a valid normative theory of European constitutionalism. This is done by mapping out four different critiques of constitutional pluralism: the historical critique, the criticism of uncertainty, the criticism of equality, and the criticism of legitimacy. Finally, the chapter discusses epistemic constitutional pluralism as a means to cope with the EU's incomplete constitutional system.

Chapter 9 concludes the argument and summarises the main findings of the book.

\subsection{THE ECONOMIC AND MONETARY UNION AND ITS CRISIS}

\subsubsection{The Constitutional Framework of the Economic and Monetary Union}

\subsubsection{The Maastricht compromise and the asymmetry of the EMU}

The Maastricht Treaty marked the formal beginning of the Economic and Monetary Union (EMU).$^{51}$ With the Treaty, ${ }^{52}$ the European Community was conferred the powers to establish the EMU. ${ }^{53}$ This meant the adoption of irrevocably fixed exchange rate policies and a single currency, which were paralleled with a single monetary and exchange rate policy. These measures aimed to secure price stability and to support the general economic policies in the Community. ${ }^{54}$ These activities were to comply with the following guiding principles: stable prices; sound public finances and monetary conditions; and a sustainable balance of payments. ${ }^{55}$

The key issue with the establishment of the EMU was how the Community's competences regarding economic policy were limited to coordination, while monetary policy was supranationalised as an exclusive Community competence. Despite this, it is sometimes forgotten that "EMU" does not stand for

51 This section builds on T. Tuominen, 'Mechanisms of Financial Stabilisation' in F. Fabbrini and M. Ventoruzzo (eds), Research Handbook on EU Economic Law (Edward Elgar Publishing 2019).

52 OJ C191/35, 29 July 1992.

53 Art. 2 EC Treaty.

54 Art. 3a(2) EC Treaty.

55 Art. 3a(3) EC Treaty. 
"European Monetary Union" but for "Economic and Monetary Union", as Harden pointed out early on. ${ }^{56}$ The term 'economic union' is a bit of a misnomer, as there is an open contrast between the single monetary policy and the multiple national economic policies. ${ }^{57}$ Thus, because of no common economic policy, the monetary union exists in a 'dangerous political vacuum'. ${ }^{58}$

In practice, the establishment of the EMU meant that the participating Member States transferred the conduct of monetary policy to the Community - to the European Central Bank (ECB). ${ }^{59}$ Yet, in the domain of economic and fiscal policy, ${ }^{60}$ the Member States retained competence for crafting their national policies as they please, while the Community gained only some oversight and coordination powers. ${ }^{61}$ In strict legal terms, when it comes to monetary policy, the actions of the Community are legally binding, whereas the coordination and oversight of economic policies consists of non-binding legal measures. This disparity between the two policies is commonly referred to as the asymmetry of the EMU. ${ }^{62}$ This has led to a conclusion that the euro is a currency without a state. ${ }^{63}$

The founding fathers of the EMU specifically wanted an asymmetrical structure. This is visible in the Delors Report:

Even after attaining economic and monetary union, the Community would continue to consist of individual nations with differing economic, social, cultural and political characteristics. The existence and preservation of this plurality would require

56 I. Harden 'The Fiscal Constitution of the EMU' in P. Beaumont and N. Walker (eds), Legal Framework of the Single European Currency (Hart Publishing 1999), p. 71 .

57 R. M. Lastra and J.-V. Louis, 'European Economic and Monetary Union: History, Trends, and Prospects' (2013) Yearbook of European Law 32(1), 57-206, p. 90.

58 K. Dyson, 'Fifty Years of Economic and Monetary Union: A Hard and Thorny Journey' in D. Phinnemore and A. Warleigh-Lack (eds), Reflections on European Integration: 50 Years of the Treaty of Rome (Palgrave Macmillan 2009), p. 159.

59 Art. 105 EC Treaty.

60 Fiscal policy is generally used to refer to government revenues and expenditures, e.g. taxes and social security benefits. Economic policy is a higher order concept, which also includes, in addition to fiscal policy, issues such as labour market conditions and industrial policy. Monetary policy is also understood as part of economic policy. See Tuori and Tuori (n 5), pp. 30-31. In this study, reference is mostly made to just economic and monetary policy, since the distinction between economic and fiscal policy is not relevant for the main argument, while the focus is on the distinction between economic and monetary policies.

61 Arts $102 \mathrm{a}-104 \mathrm{c}$ EC Treaty.

62 On this asymmetry, see Harden (n 56), pp. 71-4.

63 See T. Padoa-Schioppa, The Euro and Its Central Bank: Getting United After the Union (MIT Press 2004), pp. 35-6. 
a degree of autonomy in economic decision-making to remain with individual member countries and a balance to be struck between national and Community competences. ${ }^{64}$

If the problems that the asymmetry of the EMU posed were known already during the inception of the EMU, ${ }^{65}$ why was such an arrangement agreed upon? To simplify a bit, the underlying cause for the compromise that resulted in this asymmetry is found in the debate between the differing attitudes of the so-called 'French economists' and the 'German monetarists'. The monetarists favoured furthering monetary cooperation first and they believed that monetary cooperation together with the legal rules on the internal market would create the necessary economic convergence that would be required later, when economic integration would take place. The economists instead thought that economic policies should be integrated first so as to create the necessary economic convergence that living with a common currency requires. ${ }^{66}$ This debate provided the reason to negotiate a compromise, but the factors that contributed to the actual end result are found elsewhere.

The Maastricht Treaty and the EMU were negotiated during an era of great political change in Europe: the collapse of the Soviet Union and the unification of Germany were major events that shaped current day Europe. Garrett has argued that the German government was willing to accept the 'suboptimal', asymmetric structure of the EMU because they were keen on deepening European integration, which had now gotten new impetus due to these two large-scale political incidents. The creation of the EMU and the euro would be a logical step forward on this path. ${ }^{67}$

The German D-Mark had had a somewhat hegemonic position in Europe in terms of creating stability. Many states had actually pegged their currencies to the D-Mark, and trading prices were also relative to it. ${ }^{68}$ Economically speaking, by insisting on an institutional structure for the EMU that secured the euro's equivalent stability to that of the D-Mark, the Germans were able to avoid heavy domestic costs, although they did lose the hegemonic position of

64 Committee for the Study of Economic and Monetary Union (The Delors Committee), Report on Economic and Monetary Union in the Community (Office for Official Publications of the EC, 1989), para. 17, emphasis in the original.

65 See Lastra and Louis (n 57), p. 5.

66 See Dyson (n 58), pp. 158-61.

67 G. Garrett, 'The Politics of Maastricht' in B. Eichengreen and J. Frieden (eds), The Political Economy of European Monetary Unification. Second Edition (Westview Press 2001), p. 111.

68 See H. James, Making the European Monetary Union: The Role of the Committee of Central Bank Governors and the Origins of the European Central Bank (Belknap Press of Harvard University Press 2012), Chapter 2. 
the D-Mark and their relatively low real interest rates. However, by achieving a stable euro, German politicians were able to sell the idea to the German central bank (Bundesbank) and also to the German people who were somewhat anxious of the common currency. ${ }^{69}$ The legal structure of the EMU, and specifically that of the ECB, then followed from these political and economic imperatives. ${ }^{70}$

Furthermore, establishing a common monetary policy was made possible after the benefits of an independent central bank were recognised: essentially, how an independent central bank would insulate monetary policy and thus the achievement of price stability from politics. However, no similar reasons were found in favour of supranationalising economic policy. This was because economic policy was seen to include value judgments and trade-offs between competing interests. Such decisions, so it was seen, needed an adequate legitimacy basis that only the national polity could offer. For the same reason, no collective supervision and regulation for private banks was established, since the bailing-out of banks is done with taxpayers' money, which is also connected to similar legitimacy requirements and political sentiments. ${ }^{71}$

\subsubsection{The legal rules of the EMU in the EU Treaties}

Title VIII of the Treaty on the Functioning of the European Union contains the constitutional norms of the Economic and Monetary Union. Their content has remained essentially the same since their creation with the Maastricht Treaty, notwithstanding one small amendment adopted during the euro crisis. The asymmetrical relationship between the rules on economic policy and monetary policy is key to understanding the specific articles of Title VIII.

The general purposes and objectives of economic and monetary policy are outlined in Article 119 TFEU. The importance of Article 119 TFEU is in the principles and objectives that it contains, as these are central for the interpretation of the consequent Articles of Title VIII. The principle of an open market economy with free competition, specified in the first paragraph of Article 119 TFEU, is central for internal market law and competition law. More relevant for the context of this study are the objectives listed in the second paragraph: to maintain price stability and to support the general economic policies in the Union. Lastly, paragraph three also lists the following principles: stable prices, sound public finances and monetary conditions and a sustainable balance of payments. 
With regard to economic policy, the EU's competences are limited to coordination. This is expressly stated in Articles 2(3) TFEU and 5(1) TFEU but also visible in the articles outlining the Union's competences in practice. These rules are found in Articles 121-126 TFEU. The purpose of these rules is to manage the asymmetry of the EMU, namely to prevent government budget deficits and to subject the Member States' economic policies to the logic of the markets.

The Stability and Growth Pact (SGP) is central in this framework. It consists of a preventive and a corrective arm. The first is based on Article 121 TFEU and the latter on Article 126 TFEU. The functioning of these mechanisms has been further specified by EU secondary law instruments, ${ }^{72}$ which have been accompanied by a host of other legal instruments as a consequence of the euro crisis. $^{73}$ The preventive arm aims to ensure sound budgetary policies over the medium-term by setting parameters for Member States' economic policies and planning. These policies are assessed annually by the Commission. If a Member State fails to fulfil the set objectives, the Commission can issue the Member State with a warning and the Council can give the Member State recommendations for correcting the situation. The purpose of the corrective arm is to ensure that Member States adopt appropriate policy responses to correct excessive government deficits. The Council may sanction a Member State that has breached the objectives specified in the procedure of the preventive arm. Possible sanctions include a fine and, since 2014, the possibility to suspend part or all of the commitments or payments linked to European Structural and Investment Funds.

Article 136 TFEU provides a legal basis for developing the procedures prescribed in Articles 121 and 126 TFEU. Article 136(1) TFEU can be used to adopt measures to strengthen the coordination and surveillance of Eurozone Member States' budgetary discipline and to set out economic policy guidelines for them. ${ }^{74}$ During the euro crisis, Paragraph 3 was added to Article 136 TFEU. ${ }^{75}$

3. The Member States whose currency is the euro may establish a stability mechanism to be activated if indispensable to safeguard the stability of the euro area as a whole. The granting of any required financial assistance under the mechanism will be made subject to strict conditionality.

72 Regulation (EC) No 1466/97; Regulation (EC) No 1467/97.

73 Regulation (EC) No 479/2009; Regulation (EU) No 1173/2011; Regulation (EU) No 1174/2011; Regulation (EU) No 1176/2011; Directive 2011/85/EU; Regulation (EU) No 473/2013; Regulation (EU) No 472/2013. See Vade Mecum on the Stability \& Growth Pact. 2019 Edition. European Commission, Institutional Paper 101, April 2019.

74 See e.g. the EU secondary law measures cited supra $n 73$.

75 2011/199/EU: European Council Decision. 
The purpose of the amendment was to make it possible for the Member States to adopt a permanent financial assistance mechanism since Article 122 TFEU, discussed below, only mandates the adoption of temporary mechanisms. This amendment was effectuated through the simplified revision procedure of Article 48(6) TFEU. In the simplified revision procedure, amendments can be made to Part III of the TFEU without organising an intergovernmental conference, which is a prerequisite for amending the Treaties according to the normal revision procedure of Article 48(3) TEU. Hence, in this procedure, the European Council has to accept the proposed amendment unanimously. Following this, all Member States must ratify the change according to their national constitutions. The use of the simplified revision procedure, among other issues pertaining to the adoption of the European Stability Mechanisms (ESM), was challenged before the CJEU in Pringle. ${ }^{76}$

While Articles 121 and 126 TFEU can be seen to act as constraints on the Member States' economic policies, the Treaties also contain two rules that aim to corroborate the previously discussed framework by way of subjecting the Member States' economic policies to the logic of the markets. Article 123 TFEU specifies that overdraft facilities or any other type of credit facility with the ECB or a national central bank in favour of a Union institution or a Member State is prohibited. Furthermore, Article 123 TFEU also states that the ECB and national central banks are prohibited from directly purchasing debt instruments from the Union's institutions or the Member States. This is known colloquially as the ban on central bank financing. A related rule is found in Article 125 TFEU, according to which the EU or a Member State shall not be liable for or assume the commitments of another Member State. This is known as the no bail-out clause, since it essentially prohibits Member States from offering each other financial assistance when default is near.

The purpose of Articles 123 and 125 TFEU is to subject the Member States' economic policies to the logic of the markets: if they are unable to receive financing from the Union or other Member States, and if the Union and the other Member States are forbidden to offer financial assistance when nearing default, Member States must conduct an economic policy that allows them to secure financing from the markets. In practice, the interest rate at which a Member State can acquire financing from the markets should be dependent on their chosen economic policies, which in turn should guide them towards sustainable economic policies.

The purpose of Article 125 TFEU specifically is to ward off moral hazard concerns: if Member States or their creditors can assume that the indebted States will not ultimately be held responsible for their debt - which would

76 C-370/12 Pringle EU:C:2012:756. 
be the outcome in case of a bail-out - Member States will have an incentive to become overly indebted and banks will see the possibility of credit losses as low and therefore continue to supply cheap funding irrespective of the economic policy of the respective Member State. Due to the asymmetry of the EMU, the other Member States cannot prevent this from happening, as each Member State is in charge of their own economic policy, while the negative consequences of this ultimately affect all Member States due to the common currency.

Thus, together Articles 123 and 125 TFEU can be seen as an expression of the principle of Member States' fiscal liability. ${ }^{77}$ In other words, without these two articles the SGP would be meaningless, since independently conducted economic policies would not be independent if they were, in the end, backed up by mutual liability, that is, a bail-out by the other Member States or the ECB.

Finally, Article 122 TFEU provides for the possibility of Union financial assistance in case of crises. The first paragraph of the Article makes it possible to adopt measures to assist a Member State if severe difficulties arise in the supply of certain products, notably in the area of energy. The second paragraph facilitates giving financial assistance where a Member State is in difficulties or is seriously threatened with severe difficulties caused by natural disasters or exceptional occurrences beyond its control. Article 122 is essentially a legal base for Union action. It was first used during the euro crisis to create the European Financial Stabilisation Mechanisms (EFSM) ${ }^{78}$ and more recently in the midst of the COVID-19 crisis to create the European instrument for temporary Support to mitigate Unemployment Risks in an Emergency (SURE). ${ }^{79}$ What is important to note concerning the scope of Article 122 is that it can only be used to create mechanisms of a temporary nature, since it is meant to be used only in exceptional circumstances. ${ }^{80}$

When it comes to monetary policy, the EU has exclusive competence over monetary policy for the Member States whose currency is the euro, as specified in Article 3(1) TFEU. The ECB is tasked with defining and implementing this monetary policy, ${ }^{81}$ the primary objective of which is to maintain price stability. ${ }^{82}$ The tasks of the ECB also include the prudential supervision of

\footnotetext{
See Tuori and Tuori (n 5), pp. 32-3.

Regulation (EU) No 407/2010.

Regulation (EU) No 2020/672.

See C-370/12 Pringle EU:C:2012:756, para. 65.

Art. 127(2) TFEU.

Art. 127(1) TFEU.
} 
credit institutions, ${ }^{83}$ for which purpose there is also a separate legal basis in Article 127(6) TFEU.

The principle of central bank independence, defined in Article 130 TFEU, is vital in both institutionally positioning the ECB but also in substantively guiding its actions. The independence prescribed in Article 130 TFEU can be characterised as 'dual independence': the ECB is independent in relation to both the other EU institutions as well as the national authorities. ${ }^{84}$ This aspect is often referred to as institutional independence. From a substantive perspective, it can be said that the ECB enjoys functional independence. What this means is that the ECB has the autonomy to decide - as long as it keeps within the powers conferred on it in the Treaties - how to pursue the objective of price stability. ${ }^{85}$

The relevance of both aspects of independence become visible when considered together with the asymmetrical structure of the EMU. Institutionally speaking, since there is no common economic policy, it would be wrong for the EU or the Member States to try to affect the content of the ECB's monetary policy so that it would support the desired economic policy. Functionally speaking, since there is no common economic policy, it would be wrong for the ECB to pursue policies that would in fact have the same effects as a common economic policy. Although according to Article 127(1) TFEU the ECB 'shall support the general economic policies in the Union', as the Union does not have a proper economic policy competence, therefore the ECB's monetary policy should be kept separate from the Member States' economic policies.

It is by now common knowledge that this legal framework did not work as was envisaged. The political nature of the SGP had already become apparent before the euro crisis, when it was not enforced against Germany and France even though they had breached the deficit and debt criteria. ${ }^{86}$ During the economic boom prior to the crisis, Member States' economic policies and financial situations were not reflected in government bond interest rates. ${ }^{87}$ The logic of the markets was not functioning. Herein lies the background to the euro crisis: a common monetary policy that creates mutual interdependence, but no

\footnotetext{
83 Art. 127(5) TFEU.
}

84 R. M. Lastra, Legal Foundations of International Monetary Stability (Oxford University Press 2006), p. 224.

85 R. Smits, The European Central Bank: Institutional Aspects (Kluwer Law International 1997), p. 162-8.

86 See C-27/04 Commission v Council EU:C:2004:436. See M. Heipertz and A. Verdun, Ruling Europe: The Politics of the Stability and Growth Pact (Cambridge University Press 2010).

87 See S. Barrios et al, 'Determinants of Intra-euro Area Government Bond Spreads During the Financial Crisis' (2009) European Commission, DG Economic and Social Affairs. 
common economic policy that would stabilise this interdependence. Thus, the asymmetry of the EMU, as established in Maastricht, 'has come back to haunt Europe in the context of the European financial and euro area debt crisis' ${ }^{88}$

\subsubsection{Reasons and Reactions to the Euro Crisis}

\subsubsection{An economic narrative to the crisis}

Soon after the onset of the global financial crisis, which began from the 2007 USA subprime mortgage crisis, the economic situation of certain Eurozone Member States started to deteriorate. International rating agencies lowered the ratings for Member States' government bonds as well as those of several important national banks. This started to threaten the stability of the banking system in the Eurozone since due to the common currency and mutual borrowing the still stronger countries and banks were also affected. If in the USA the fall of Lehman Brothers in 2008 was the decisive moment, in Europe it was the announcement by the Greek Prime Minister George Papandreou in October 2009 that the debt and deficit levels previously reported by Greece had been tremendously wrong. After this announcement 'the euro decisively ceased being boring' ${ }^{89}$

While all of this affected various parts of the Eurozone differently, some common denominators can be found. Ireland and Spain were hit by the initial global financial crisis. When consumption plummeted, the construction sector in particular faced problems. Greece, Portugal and Italy were hit by a fiscal crisis caused by their own government spending. The northern European creditor countries were hit by a balance of payments crisis, as suddenly capital started to flow out from them. National governments failed to react to these problems, since cheap debt was available due to the euro. Monetary stability did not mean financial stability, and due to its strict monetary policy mandate, the ECB had no way of tackling this. The link between governments and banks meant that it was difficult for sovereigns to react to the crisis.

After the initiation of the financial crisis in Europe, it soon became obvious that the most indebted and economically weak Eurozone Member States might actually face default. This, so it was perceived, could consequently threaten the existence of the whole euro. Due to a home bias in holding of sovereign debt by banks, sovereign default in the Eurozone also results in the private banks of that country running into trouble, as they are no longer able to receive liquidity

${ }^{88}$ F. Amtenbrink, 'The Metamorphosis of European Economic and Monetary Union' in A. Arnull and D. Chalmers (eds), The Oxford Handbook of European Union Law (Oxford University Press 2015).

${ }^{89}$ J. Pisani-Ferry, The Euro Crisis and Its Aftermath (Oxford University Press 2014), p. 8. 
from the ECB because the sovereign debt they hold is worthless and thus not suitable as collateral. The only option left would be to exit the Eurozone, and thus regain sovereignty over monetary policy. Furthermore, default by one Eurozone Member State would have given the markets a signal that investments in other crisis states were not safe either, resulting in their debt refinancing costs soaring and therefore also bringing them closer to default. Such contagion was seen to threaten the existence of the euro. Whether or not this would have resulted in the break-up of the euro, we will never know, but the economic consequences of this would have been catastrophic no doubt. In this situation, giving financial assistance to both states and banks seemed the best and only option, since the link between the two had not yet been severed.

However, it was the political consequences that were most feared. This sentiment is depicted well in the words of the German Chancellor Angela Merkel: 'If the euro fails, Europe fails.' ${ }^{90}$ This attitude - of being ready and willing to do 'whatever it takes' to preserve the euro ${ }^{91}$ - is important for understanding the political events that resulted in the uptake of the various crisis response mechanisms, as well as their subsequent constitutionalisation by the CJEU in Pringle and Gauweiler. ${ }^{92}$

\subsubsection{An overview of the crisis response measures}

The magnitude of the euro crisis is reflected well in the myriad legal measures that the EU and the Member States, both together and on their own part, took to combat the crisis and to prevent future crises. Although only one small amendment to the EU Treaties was adopted as a consequence of the crisis, several scholars have described these reactions as amounting to no less than the transformation of the EU's economic governance regime, if not its constitutional structure more generally speaking. ${ }^{93}$ A general criticism towards these measures has been that they were adopted in haste and under enormous economic pressure, yet without due consideration for what would have been the best possible option. ${ }^{94}$

90 "'If the Euro Fails, Europe Fails": Merkel Says EU Must Be Bound Closer Together': Spiegel Online (7 September 2011) http://www.spiegel.de/international/ germany/if-the-euro-fails-europe-fails-merkel-says-eu-must-bebound-closer-together -a-784953.html (accessed 1 September 2020).

${ }_{91}$ Speech by Mario Draghi, President of the European Central Bank at the Global Investment Conference. London, 26 July 2012. The whole sentence was: 'Within our mandate, the ECB is ready to do whatever it takes to preserve the euro. And believe me, it will be enough.'

92 See C-370/12 Pringle EU:C:2012:756; C-62/14 Gauweiler EU:C:2015:400.

93 See e.g. Tuori and Tuori (n 5); Amtenbrink (n 88); Borger (n 6).

94 See Fabbrini (n 9), p. 1. 
How these measures were adopted is not explained here, as that will be addressed in detail in the four case studies. The purpose of this section is to give a brief overview of the mechanisms. This will reduce the need for repetition later on and also familiarise the reader with these measures at once. Even though each mechanism is analysed in a separate chapter, due to linkages between the measures, references are made between the case studies. In other words, understanding the rationale of one measure requires understanding all of them.

During the height of the euro crisis, several Member States were either at the brink of defaulting on their creditors or their debt refinancing costs were so high that they would soon find themselves in such a position. For this reason, financial assistance was given to Member States, as it was seen as a better alternative than letting some of the states default and perhaps exit the Eurozone. Thus, the purpose of these measures was also to safeguard financial stability, for which reason these measures have also been referred to as financial stabilisation mechanisms. In practice, such measures can be termed rescue packages or even bail-outs.

Assistance given by the Member States was first based on direct bilateral loans between the Member States but was eventually formalised under three different mechanisms. First, there was the EFSM, established with Regulation (EU) No 407/2010..$^{5}$ Second, the European Financial Stability Facility (EFSF) was established as a company incorporated in Luxembourg under Luxembourgish law and owned by the Eurozone Member States. Third, the European Stability Mechanism (ESM) was adopted as a treaty between the Member States based on international law, concurrently with the above-mentioned amendment to Article 136 TFEU. Such financial assistance mechanisms were completely novel, as similar ones did not exist before the crisis.

Financial assistance was also given to private banks. The events of the banking crisis have been closely described in the literature.$^{96}$ Initially, the lack of EU-level resolution and recovery rules resulted in State aid rules taking their place. Financial assistance to private banks was given explicitly in the form of State aid, as prescribed in Article 107 TFEU, first on the basis of Article 107(3)(c) TFEU and the 2004 Restructuring Guidelines, ${ }^{97}$ and later on

\footnotetext{
95 Regulation (EU) No 407/2010.

96 See e.g. F.-C. Laprévote and F. de Cecco (eds), Research Handbook on State Aid in the Banking Sector (Edward Elgar Publishing 2017).

97 Communication from the Commission - Community guidelines on State aid for rescuing and restructuring firms in difficulty. OJ C 244, 1.10.2004, pp. 2-17.
} 
the basis of Article 107(3)(b) TFEU and the 2008 Banking Communication. ${ }^{98}$ The bulk of bank bail-outs were then made according to the 2008 Banking Communication, with Article 107(3)(b) TFEU as their legal basis. ${ }^{99}$

In 2013 a new Banking Communication was adopted. ${ }^{100}$ This Communication reflected the change in European leaders' attitudes towards solving the crisis. As a result of Angela Merkel and Nicolas Sarkozy's meeting in Deauville on 19 October 2010, ${ }^{101}$ the emphasis shifted from bail-out towards bail-in. Such a shift is in line with the Maastricht macroeconomic principle of Member States' fiscal liability and the no bail-out clause of Article 125 TFEU, as it aims at inducing market discipline. When the same approach is applied to private banks, it is called 'private sector involvement'. ${ }^{102}$ It needs to be reiterated that the bail-out approach utilising State aid was used before the adoption of the Banking Union.

As giving financial assistance to profligate states amounts to a Sisyphean task - or at least so the sentiment seemed to be at the time - the adoption of financial assistance mechanisms was quickly followed by tighter budgetary constraints. The Six-Pack was introduced to increase the effectiveness of the preventive and corrective arms of the SGP. ${ }^{103}$ The Six-Pack also created the European Semester, a procedure whereby the Member States' budgets are subjected to review by the Commission, who assesses whether the budgets meet the new criteria created by the Six-Pack. ${ }^{104}$ Later, the Two-Pack was adopted to further increase the Commission's surveillance powers over the Member States' budgets, although still leaving the final decision on the content of the budgets to the national parliaments, as the EU has no proper economic policy competence. ${ }^{105}$ The Two-Pack enhanced the surveillance of draft budgetary

98 Communication from the Commission - The application of State aid rules to measures taken in relation to financial institutions in the context of the current global financial crisis, OJ C 270, 25.10.2008, pp. 8-14.

99 See supra n 96.

100 Communication from the Commission on the application, from 1 August 2013, of State aid rules to support measures in favour of banks in the context of the financial crisis ('Banking Communication'), OJ C 216, 30.7.2013, pp. 1-15.

101 See 'Franco-German Declaration' (18 October 2010) https://archiv .bundesregierung.de/archiv-en/articles/franco-german-declaration-756384 (accessed 1 September 2020).

102 See M. K. Brunnermeier, H. James and J.-P. Landau, The Euro and the Battle of Ideas (Princeton University Press 2016), pp. 1 and 29-33.

103 Regulation (EU) No 1175/2011; Regulation (EU) No 1177/2011; Regulation (EU) No 1173/2011; Directive 2011/85/EU; Regulation (EU) No 1176/2011; Regulation (EU) No 1174/2011.

104 See K. A. Armstrong, 'The New Governance of EU Fiscal Discipline' (2013) European Law Review 38(5), 601-17.

105 Regulation (EU) No 473/2013; Regulation (EU) No 472/2013. 
plans by building on the preventive arm of the SGP and it also facilitated the common budgetary timeline of the European Semester.

In addition to these EU secondary law measures the Treaty on Stability, Coordination and Governance in the Economic and Monetary Union (TSCG or Fiscal Compact) was adopted as a measure between the Member States, based on international law. Its objectives are similar to those of the Six-Pack and Two-Pack, but its mode of operation is to effectuate changes through the Member States' national laws. Thus, it complements the other measures in an innovative way. ${ }^{106}$ As opposed to the new mechanisms of financial assistance, rules on budgetary constraints existed already prior to the crisis but they were made considerably more stringent with these amendments.

As the fate of the Member States' economies is heavily connected to the fate of the private banks domiciled in them, which was already pointed out above by the bail-outs given to private banks in the beginning of the crisis, a legal mechanism directed towards the problems that the banks were facing was also deemed necessary. ${ }^{107}$ The regulatory actions aimed at private banks ('credit institutions') comprise a vast variety of measures. On one hand, there are the general measures that are in force in the whole EU. These were enacted first. They are referred to as the 'Single Rulebook' and they aim to complete the single market for financial services. ${ }^{108}$ The Single Rulebook regulates capital requirement for banks, prevention and management of bank failures, and protection of depositors. In practice, the most important elements of the Single Rulebook are the Capital Requirements Directive IV (CRD IV), ${ }^{109}$ the Capital Requirements Regulation (CRR), ${ }^{110}$ the Bank Recovery and Resolution Directive (BRRD), ${ }^{111}$ and the Deposit Guarantee Scheme Directive (DGSD). ${ }^{12}$

On the other hand, there is the European Banking Union, which is substantively based on the application of the EU secondary law instruments comprising the Single Rulebook, but which applies only to the Eurozone Member States (non-Eurozone countries can also join). The purpose of the Banking Union is to create centralised forms of supervision and resolution that apply

106 See P. Leino-Sandberg and J. Salminen, 'A Multi-Level Playing Field for Economic Policy-Making: Does EU Economic Governance Have Impact?' in T. Beukers, B. de Witte, and C. Kilpatrick (eds), Constitutional Change through Euro-Crisis Law (Cambridge University Press 2017).

107 On the link between the banks and the states, see N. Véron, Europe's Radical Banking Union (Bruegel 2015), pp. 14-19.

108 See Council of the European Union, Presidency Conclusions, 11225/2/09. Brussels, 10 July 2009.

109 Directive 2013/36/EU.

110 Regulation (EU) No 575/2013.

111 Directive 2014/59/EU.

112 Directive 2014/49/EU. 
to banks situated in the Member States that are part of the Banking Union. The new mechanisms established for this purpose are the Single Supervisory Mechanism (SSM) ${ }^{113}$ and the Single Resolution Mechanism (SRM). ${ }^{114}$ In order to provide a back-stop to wind down failing banks, the Single Resolution Fund (SRF) was attached to the SRM. National contributions to the SRF have been transferred and mutualised with the Single Resolution Fund Treaty (SRF Treaty). ${ }^{115}$ The third pillar of the Banking Union, the proposed European Deposit Insurance Scheme, ${ }^{116}$ has still not been adopted. While there were some rules related to banks prior to the crisis, ${ }^{117}$ this regulatory dimension is mostly novel too.

Separately from the substantive banking regulations, and actually already before it, the European System of Financial Supervision was established in 2010. This supervisory architecture consists of three supervisory authorities - the European Banking Authority, the European Securities and Markets Authority, and the European Insurance and Occupational Pensions Authority accompanied by the European Systemic Risk Board. ${ }^{118}$ These bodies supervise the whole EU and not just the Eurozone.

The last group of measures that needs to be mentioned here are the various operations undertaken by the ECB. Their objective has been to support financial stability and economic recovery within the EMU. These activities have taken two forms. First, there are the open market operations, which aim to inject liquidity into the real economy and to signal the monetary policy stance in the euro area. Second, there are the various asset purchase programmes, which, by definition, are a form of non-standard monetary policy measures. Through such programmes the ECB purchases government bonds, securities issued by European supranational institutions, corporate bonds, asset-backed securities and covered bonds with the aim of thus influencing financial conditions such as economic growth and inflation. The three most discussed programmes are perhaps the Securities Markets Programme (SMP), ${ }^{119}$ the

113 Regulation (EU) No 1024/2013; Regulation (EU) No 1022/2013.

114 Regulation (EU) No 806/2014.

115 Agreement on the transfer and mutualization of contributions to the Single Resolution Fund. Council of the European Union, ECOFIN 342. Brussels, 14 May 2014.

$116 \mathrm{COM} / 2015 / 0586$ final.

117 See L. Dragomir, European Prudential Banking Regulation and Supervision: The Legal Dimension (Routledge 2010).

118 Regulation (EU) No 1092/2010; Regulation (EU) No 1096/2010; Regulation (EU) No 1093/2010; Regulation (EU) No 1094/2010; Regulation (EU) No 1095/2010; Directive 2010/78/EU.

119 Decision of the European Central Bank of 14 May 2010 establishing a securities markets programme $(\mathrm{ECB} / 2010 / 5)$. 
Outright Monetary Transaction Programme (OMT), ${ }^{120}$ and the Public Sector Purchase Programme (PSPP). ${ }^{121}$ The controversial aspect of such programmes is how the ECB acquires Eurozone Member States' government bonds - from the secondary markets, since Article 123 TFEU forbids the ECB from buying them directly from the Member States - with the aim of thus lowering their interest rates or making them attractive to private investors in the first place. Thus, such programmes seem to contravene the rules of Articles 123 and 125 TFEU. For this reason, the OMT programme resulted in the case Gauweiler and the PSPP in the case Weiss. ${ }^{122}$

\subsubsection{The Link Between an Asymmetrical Economic and Monetary Union and a Dysfunctional Constitutional Order}

Soon after the adoption of the EEC Treaty, Mundell presented his theory of optimal currency areas, which contained the so-called unholy trinity argument. ${ }^{123}$ According to this thesis, the following three conditions are mutually incompatible within a common currency area and only two can co-exist at any one time: fixed exchange rates; independent monetary policies; and full capital mobility. Economists have since widely accepted the thesis, and it has become the standard for assessing the EMU from an economic perspective. ${ }^{124}$ In another influential model, free trade between the countries is added as a fourth variable, in which case the thesis is referred to as the inconsistent quartet. ${ }^{125}$

Later, similar theses have been presented that pose further challenges to the EMU. Rodrik's trilemma of globalisation posits the following three variables, out of which only two can co-exist: hyperglobalisation; the nation state; and democratic politics. ${ }^{126}$ This results in the following three possible combinations: (i) choosing hyperglobalisation and democracy results in discharging

120 Technical features of Outright Monetary Transactions. ECB press release, 6 September 2012, https://www.ecb.europa.eu/press/pr/date/2012/html/pr120906_1.en .html (accessed 1 September 2020).

121 Decision (EU) 2015/774 of the European Central Bank of 4 March 2015 on a secondary markets public sector asset purchase programme.

122 See C-62/14 Gauweiler EU:C:2015:400; C-493/17 Weiss EU:C:2018:1000.

123 See R. Mundell, 'Theory of Optimum Currency Areas' (1961) American Economic Review 51(4), 657-66.

124 See K. McNamara, 'Economic Governance, Ideas and EMU: What Currency Does Policy Consensus Have Today?' (2006) Journal of Common Market Studies 44(4), 803-21, p. 805.

${ }_{125}$ See T. Padoa-Schioppa, The Road to Monetary Union in Europe: The Emperor, the Kings, and the Genies (Oxford University Press 2000), Chapter 2.

126 See D. Rodrik, The Globalization Paradox: Democracy and the Future of the World Economy (W. W. Norton \& Company 2011), pp. 200-206. 
with the nation state; (ii) selecting democracy and the nation state means that globalisation is not possible, at least to the same extent; (iii) opting for the nation state and hyperglobalisation results in sacrificing democracy. In the first case, rules are made internationally so there are no transaction costs, but then national sovereignty is lost since the nation state does not decide anymore. In the second case, having two different sets of rules results in transaction costs, which hinders international economic integration. The third case has been referred to as the 'Golden Straitjacket', since in this case, although decisions are made in the nation state, the decisions are affected by the pressure of the international markets and thus end up producing rules that favour the markets at the expense of democracy.

Snell has schematised the development of the EMU through the three different choices offered by Rodrik's trilemma. First, we had an incomplete EMU, which allowed us to preserve mass politics and nation states. This, however, resulted in the EMU being vulnerable and not working. Second, as a response to the Eurozone crisis, we now have an EMU in which we try to strengthen economic integration while still maintaining national sovereignty. This, however, has led to mass politics being disregarded and to decisions imposed by the 'Golden Straitjacket'. Third, we have the blueprints for the future EMU, which emphasise economic integration and mass politics. This, however, would lead to national sovereignty being sacrificed, since it would be replaced by supranational democracy. ${ }^{127}$

What would this third stage mean? Snell's analysis of this is especially relevant for this study. First, there is a trade-off between national sovereignty and a single currency. The former has to be limited if the latter is to work. Those wishing to preserve national sovereignty have to realise the price they must pay for it. The German Federal Constitutional Court was endeavouring to argue for national democracy (sovereignty) in Gauweiler. ${ }^{128}$ In its argumentation, the German court effectively chose national democracy (sovereignty) over a functioning single currency.

Second, the legitimacy of the EMU can also be analysed through this framework. The initial EMU lacked output legitimacy, while the crisis response measures lacked input legitimacy. Despite the crisis response mechanisms being able to save the euro, due to their undemocratic nature, such output legitimacy might not be enough to counter the inadequacies in input legitimacy. In order to redress this, mass politics (democracy) should be deployed at the

127 J. Snell, 'The Trilemma of European Economic and Monetary Integration, and Its Consequences' (2016) European Law Journal 22(2), 157-79, pp. 160-71.

128 See 2 BvR 2728/13, 14 January 2014 (OMT reference); 2 BvR 2728/13, 21 June 2016 (OMT final judgment). 
supranational level. This, though, can be difficult. Therefore, the legitimacy problem would be worsened when trying to transfer mass politics from the national to the supranational level. On the other hand, since returning to national currencies does not seem a plausible solution, what are we to do? These points notwithstanding, Snell concludes in a Habermasian fashion that we must strive to build a transnational model of democracy. ${ }^{129}$

Snell's analysis of the euro crisis and its consequences seems to reproduce the more general problem underlying European constitutionalism: due to the pluralist nature of the current constellation, the sovereignty debate is ever-persistent. Snell's analysis offers a substantive reason explaining why there are competing claims to sovereignty by the Member States and especially by national courts. It also brings forth why normative pluralism, based on mutual deference and concession, does not work: what if the different courts are not able to find mutual ground in such trade-off situations as presented by these trilemmas? The answer that Snell presents in relation to Rodrik's trilemma and the EMU also hints towards the same direction as the answer to countering the problems stemming from constitutional pluralism: of introducing a political union; of furthering European integration; and of having structural rules on settling such debates instead of relying on conflict rules applied by courts.

\subsection{CONSTITUTIONAL PLURALISM}

\subsubsection{Introducing Constitutional Pluralism}

Let us start with two contrasting narratives on European constitutionalism, one from Luxembourg and the other from Karlsruhe. According to the first, authority, as far as it is transferred to the EU according to the doctrine of conferred powers, rests with the Union and thus the Union's new legal order is autonomous. This is the view expounded by the CJEU in its landmark rulings. ${ }^{130}$ The opposing view, offered by the German Federal Constitutional Court, holds that the authority that the Union is able to exert is deduced from the authority of the Member States, their national constitutions, which consequently means that they have the final say. This also ultimately means that the Member States retain absolute sovereignty. ${ }^{131}$ Tuori's explanation of this in Kelsenian terms is

\footnotetext{
129 Snell (n 127), pp. 171-8.

130 See e.g. case 26/62 van Gend en Loos EU:C:1963:1; 6/64 Costa v E.N.E.L. EU: C:1964:66; C-399/11 Melloni EU:C:2013:107.

131 See e.g. BVerfGE 37, 271 (Solange I); BVerfGE 73, 339 (Solange II); BVerfGE 89, 155 (Maastricht); BVerfGE 123, 267 (Lisbon); 2 BvR 2661/06 (Honeywell); 2 BvR 2728/13, 14 January 2014 (OMT reference).
} 
enlightening: the claim made in Luxembourg implied a change in the national Grundnorm, since through the principle of primacy, the CJEU claimed the highest position for EU law within the national legal order, which also meant that the Member States had divided their sovereignty to the benefit of the EU. Karlsruhe's reply was that the national constitution is still the Grundnorm, according to which EU law is to be interpreted and applied in Germany. ${ }^{132}$

Constitutional pluralism as an academic project was sparked by the German Federal Constitutional Court's decision regarding the ratification of the Treaty of Maastricht. ${ }^{133}$ Simply put, constitutional pluralism can be described as an attempt to analyse the interaction between national courts and the CJEU and how conflicts between them could be avoided via some form of mutual deference. Such deference is seen to unfold through a dialogue between courts. ${ }^{134}$ In essence, pluralists - those ascribing to constitutional pluralism as an apt normative theory of European constitutionalism - reject both the view of the CJEU and that of the German court and propose a third, alternative view. Under this view, both systems can co-exist, overlap and interlock without a hierarchy. Instead, they try to find other ways of reconciliation between the two systems. ${ }^{135}$ Some, however, hold the view that constitutional pluralism is merely a theory that tries to validate and legitimise national courts giving precedence to national rather than EU law. ${ }^{136}$ This perception is perhaps based on the finding that national constitutions can 'gain much more from pluralism than the European position'. ${ }^{137}$

In an early article on the topic, Walker mapped out the three claims of constitutional pluralism. ${ }^{138}$ This categorisation is still a relevant starting point for understanding constitutional pluralism in general, and it also serves as an inroad into the discussion on constitutional pluralism conducted in this book.

132 K. Tuori, 'The Many Constitutions of Europe' in K. Tuori and S. Sankari (eds), The Many Constitutions of Europe (Ashgate 2010), p. 20.

133 BVerfGE 89, 155 (Maastricht). See Baquero Cruz (n 23).

134 See e.g. T. Tridimas, 'The ECJ and the National Courts: Dialogue, Cooperation, and Instability' in Arnull and Chalmers (n 88); B. de Witte, 'The Preliminary Ruling Dialogue: Three Types of Questions Posed by National Courts' in B. de Witte et al (eds), National Courts and EU Law: New Issues, Theories and Methods (Edward Elgar Publishing 2016).

135 See N. Walker 'The Philosophy of European Union Law' in Arnull and Chalmers, ibid., pp. 23-6.

136 M. Claes, 'The Primacy of EU Law in European and National Law' in Arnull and Chalmers, ibid., p. 202.

137 Baquero Cruz (n 23), p. 414.

138 See N. Walker, 'The Idea of Constitutional Pluralism' (2002) Modern Law Review 65(3), 317-59, pp. 337-9. Also see N. Walker, 'Late Sovereignty in the European Union' in N. Walker (ed.), Sovereignty in Transition (Hart Publishing 2003), p. 4. 
First, there is the descriptive claim. Namely, that we can observe the existence of overlapping constitutional regimes, since within the Member States both their national constitutions and the EU's constitutional order are in force simultaneously. These overlapping constitutional regimes posit competing constitutional claims. These claims are most clearly articulated in cases in which there is disagreement as to whether the issue should be settled according to national law or EU law, or whether the final arbiter in the situation is a national court or the CJEU. In the above-mentioned PSPP case, the CJEU first declared the ECB's PSPP as being within the ECB's mandate. This decision was based on an interpretation of the EU Treaties. The CJEU thought that it - and only it - had the competence to rule on the interpretation of the EU Treaties and on the validity of acts by an institution of the Union, as stipulated in Article 267 TFEU. ${ }^{139}$ However, the German Federal Constitutional Court then declared the PSPP and the CJEU's judgments as ultra vires. The German court based its ruling both on its interpretation of the EU Treaties and the German constitution. ${ }^{140}$ In essence, both courts assumed the position of the final arbiter in the matter, whereas in reality only one court can decide what happens to the ECB's PSPP.

Second, there is the normative claim, which goes beyond the mere descriptive claim by first acknowledging the plurality of constitutional regimes and constitutional claims, and then by embracing the implications of this. Thus, whereas the descriptive claim signals the mere acknowledgement of plurality, the normative claim embraces it and turns it into pluralism. The normative claim thus deduces what ought to be from what is. That is to say, normative pluralism recognises the somewhat incomplete nature of the EU's constitutional system (that there are competing constitutional claims), but decides to turn it into a virtue by positing that this is how it ought to be. Furthermore, most often normative pluralism also argues that such competing claims are in fact a beneficial way of reconciling the different political views as expressed by the constitutions of the Member States and the EU. Again, to use the PSPP case as an example, normative pluralism could argue, for example, that it is in fact desirable that national courts question the ECB's actions and pressure the CJEU to conduct its review in a prudent manner, since otherwise the ECB could act outside its mandate. The fact that the Federal Constitutional Court sends a tersely formulated referral to the CJEU will not result in the eradication of the EU's constitutional system, since in the end, a solution to the situation will be found by the courts.

139 C-493/17 Weiss EU:C:2018:1000.

1402 BvR 859/15, 05 May 2020 (PSPP judgment). 
Third, there is the epistemic claim, which is necessitated by the normative claim, if taken seriously. If the EU and its Member States are understood as distinct constitutional sites, then this also implies the incommensurability of their respective claims to constitutional authority. Therefore, in order for us to understand the competing sovereignty claims as true sovereignty claims, we have to adopt a new, pluralist epistemology. That is to say, we have to appreciate the competing sovereignty claims from their own starting points and thus as not mutually exclusive. This requires acknowledgement that 'there is no neutral perspective from which their distinct representational claims can be reconciled'. ${ }^{141}$ In other words, various epistemic starting points need to be adopted. As sovereignty is traditionally understood in ultimate terms, terms such as 'shared' or 'disaggregated' sovereignty would be oxymorons, because for us to truly appreciate the normative claim of constitutional pluralism requires us to adopt a new conceptualisation of sovereignty, and along with that a new constitutional vocabulary and grammar with which to speak this new constitutional language. The epistemic strand of constitutional pluralism is geared towards this purpose. ${ }^{142}$ In practice, this is perhaps best described as an exercise in constitutional and political theory that aims to develop old categories and concepts so as to better match current reality - and more importantly, to aid in further developing the EU as a polity beyond the constraints that the old state-based constitutional concepts place on our constitutional imagination. ${ }^{143}$

Having become the dominant theory and accepted paradigm in European constitutionalism, the literature on constitutional pluralism, as well as the different views expressed therein, is vast. ${ }^{144}$ For the sake of brevity, the pluralist accounts are here divided into two groups. First, we have the normative pluralists, who focus their attention on creating or explicating conflict rules according to which the clashes between the national courts and the CJEU could be reconciled. Second, we have the epistemic pluralists, who in turn are more interested in conceptualising this new state of affairs in terms of constitutional theory. Both strands of scholarship will be briefly introduced next.

\subsubsection{Normative Constitutional Pluralism}

Since normative pluralism appraises the plurality of constitutional sites and constitutional claims, in order for it to offer a viable constitutional framework,

141 Walker, 'The Idea of Constitutional Pluralism' (n 138), pp. 338-9.

142 See Walker, 'Late Sovereignty in the European Union' (n 138), pp. 10-18.

143 See N. Walker, 'European Constitutionalism in the State Constitutional Tradition' (2006) Current Legal Problems 59(1), 51-89.

144 See supra $\mathrm{n} 11$. 
it needs to address the apparent clashes between national courts and the CJEU. So, how should situations in which a national law and EU law - or interpretation by a national court and the CJEU - contradict each other be resolved? Several different alternatives have been put forward in the literature. I will call such propositions conflict rules, since their purpose is to settle constitutional conflicts between the Member States and the EU.

Various sources have been used to distinguish such conflict rules. To begin with, for Maduro these are his 'harmonic principles of contrapunctual law', which include pluralism, consistency and coherence, universalisability, and institutional choice. ${ }^{145}$ In a somewhat similar manner, Kumm has posited his 'principle of best fit', that is, rules that would best realise the ideals underlying legal practice in the EU and the Member States. In practice, these include the formal principle of legality, jurisdictional principles of subsidiarity, the procedural principle of democracy, and the substantive principle of the protection of basic rights or reasonableness. ${ }^{146}$ For Besselink, a conflict rule is already provided by the principle of primacy of EU law, and granting primacy to EU law over national law is justified on the basis of the principles of the consistent interpretation and useful effect of EU law, which do not imply a hierarchy as such between the European and the national legal orders. ${ }^{147}$

Then there are approaches that build on the national identity clause of Article 4(2) TEU. According to von Bogdandy and Schill, the principle of national constitutional identity, as balanced against the principle of uniform application of EU law, contains the proper conflict rule. ${ }^{148}$ In a somewhat similar manner, Bobic argues for an 'auto-correct function', which on behalf of the European Union is based on the national identity clause of Article 4(2) TEU, and on behalf of the Member States on an EU-friendly interpretation of national constitutional law (Europafeindlichkeit). ${ }^{149}$

145 See e.g. M. P. Maduro, 'Contrapunctual Law: Europe's Constitutional Pluralism in Action', in N. Walker (ed.), Sovereignty in Transition (Hart Publishing 2003), pp. 524-31.

146 M. Kumm, 'The Jurisprudence of Constitutional Conflict: Constitutional Supremacy in Europe Before and After the Constitutional Treaty' (2005) European Law Journal 11(3), 262-307, p. 299.

147 L. Besselink, A Composite European Constitution (Europa Law Publishing 2007), p. 9.

${ }_{148}$ A. von Bogdandy and S. Schill, 'Overcoming Absolute Primacy: Respect for National Identity under the Lisbon Treaty’ (2011) Common Market Law Review 48(5), 1417-54.

149 A. Bobić, 'Constitutional Pluralism Is Not Dead: An Analysis of Interactions Between Constitutional Courts of Member States and the European Court of Justice' (2017) German Law Journal, 18(6), 1395-428. 
A common argument made by the authors propagating the use of such conflict rules as an answer to the competing constitutional claims is that such claims actually induce legitimacy into the EU's constitutional and political system. This is because, as Maduro has explained, the normative claim of constitutional pluralism necessarily entails that such competing claims 'are of equal legitimacy or, at least, cannot be balanced against each other in general terms'. ${ }^{150}$

Under Maduro's account, as the competences of the EU are not and cannot be explicitly defined (in which case the Union's actions would be legitimised by the EU Treaties as such), the only way to constantly legitimise the Union's actions is through a constitutional discourse between the CJEU and the national courts. ${ }^{151}$ This is also what occurred during the early days of European integration, when the CJEU was constructing the 'new legal order': 'It was the support of a broad constituency of legal actors (mainly national courts and litigants) that "authorised" the European Court of Justice to "free" EU law from indirect legitimacy through the State and make a claim of independent and political authority.' ${ }^{152}$ Conversely, Kumm has argued that 'concerns related to democratic legitimacy override considerations relating to the uniform and effective enforcement of EU law' and thus national courts can in some cases set aside EU law if it conflicts with national law. ${ }^{153}$ This is because of the democratic deficit of the EU. ${ }^{154}$ Adopting a more theoretical perspective, Walker has maintained that under a pluralist framework, 'the overlap of heterarchically related constitutional authorities of the common part and the local parts, rather than undermining or eroding the legitimacy of each such authority, becomes a condition of legitimacy of the combined whole'. ${ }^{155}$

Such claims bring forth the question of whether national courts can actually induce legitimacy into the EU's constitutional and political system, be it conceptualised in pluralist or monist terms. It is of course true that in some cases the concerns with which national courts have pressed the CJEU have been very legitimate and have resulted in overall desirable outcomes - think of the original Solange case law and the introduction of fundamental rights into EU

150 M. P. Maduro, 'Three Claims of Constitutional Pluralism', in M. Avbelj and J. Komárek (eds.), Constitutional Pluralism in the European Union and Beyond (Hart Publishing 2012), p. 75.

151 Maduro (n 145), p. 537.

152 Ibid., pp. 517-18.

153 Kumm (n 146), p. 298.

154 Ibid., p. 300.

155 N. Walker, 'Constitutional Pluralism Revisited' (2016) European Law Journal 22(3), 333-55, p. 352. 
law. ${ }^{156}$ This is the 'bottom-up effect' that Maduro alludes to. ${ }^{157}$ However, this is not always the case. Sometimes national courts defy decisions taken at the European level, yet on the basis of a single national constitution. The direst example of this is the German Federal Constitutional Court's PSPP judgment.

How can a single national court, acting as the guardian of its national constitution, induce legitimacy into a political process that has taken place at the highest level of politics in Europe? How can a national court, as a legal institution, induce legitimacy into a decision taken by technocratic experts of a given field (e.g. monetary policy)? Furthermore, as there are differences in the way in which national courts can engage in such activity, what does this mean with regards to the legitimacy of such actions? That is to say, if some national courts are better placed to engage in a dialogue with the CJEU, and to thus try to alter the course of European politics or the content of EU law, where does this leave the rest of the national courts? Is there an inherent inequality between the national courts in this regard? It would seem, thus, that both substantively and structurally, the actions of national courts often do exactly the opposite than to induce legitimacy.

\subsubsection{Epistemic Constitutional Pluralism}

Let us still briefly address epistemic pluralism. In addition to the above-discussed legitimacy issues, taking normative pluralism seriously also leads to acknowledging the necessity of epistemic pluralism. If the existence of simultaneously existing and truly competing sovereignty claims is acknowledged, then to account for this state of affairs we are required to adjust our understanding of what sovereignty means. The purpose of epistemic pluralism is just this: to envisage what constitutionalism beyond the state would look like. In fact, one of constitutional pluralism's aims is to offer an explanation of the current constitutional arrangement that would facilitate constitutional discourse in a new way. This is necessary if we are to avoid 'middle-range theorizing' - that is, explaining the system with the system's own terms. ${ }^{158}$

156 See Stone Sweet (n 31), pp. 170-74.

157 M. P. Maduro, 'Europe and the Constitution: What if This is as Good as it Gets?' in J. H. H. Weiler and M. Wind (eds), European Constitutionalism beyond the State (Cambridge University Press 2003), p. 98, where Maduro explains how 'the legitimacy of European constitutionalism has developed in close cooperation with national courts and national legal communities which have an increasing bottom-up effect on the nature of the European legal order'. See also Maduro (n 145), pp. 517-18.

158 Walker (n 22), p. 585. 
Walker, having coined the term epistemic pluralism, ${ }^{159}$ is perhaps the leading figure within this group of scholars. Walker has posited that the originally international law-based Community, which has since claimed its 'independence' based on the existence of its own 'new legal order', now makes relevant constitutional claims; claims that exist in harmony with those older claims originating from the Member States. The relationship of the old and the new - the state and the post-state - is thus best characterised as 'horizontal rather than vertical - heterarchical rather than hierarchical'. ${ }^{160}$ Consequently, a key point in Walker's pluralism is the acknowledgement that although there are different sites of constitutional authority, this does not necessarily lead to one site subsuming authority over the other, and furthermore, that there would not exist any constitutional authority without the existence of such a hierarchy. In this way constitutional pluralism tries to retain the key element of constitutionalism (a single authorising political domain) while also embracing the diversity of that domain (the multiple sites of authority). ${ }^{161}$ Being the leading theory of European constitutionalism, constitutional pluralism encompasses a wide range of theories and premises. This notwithstanding, there seems to be one key element that unites all pluralists: a very thin understanding of heterarchy, as opposed to some form of hierarchy between the European and national levels. ${ }^{162}$

\subsection{CONCLUSIONS}

Following the German Federal Constitutional Court's PSPP judgment in May 2020, we can say that constitutional pluralism has now come full circle: the discussion was first sparked by the German court's ruling on the ratification of the Maastricht Treaty in $1993,{ }^{163}$ with which the EMU was established. Since then there have been several rulings by national courts that assumed similarly critical stances towards European integration and EU law. These judgments have been considered as parts of a dialogue amongst European courts, which, supposedly, induces legitimacy into the EU's constitutional order. A crucial

\footnotetext{
159 See Walker (n 138), p. 338.

160 Ibid., p. 337. Similarly, see N. MacCormick, 'The Maastricht-Urteil: Sovereignty Now' (1995) European Law Journal 1(3), 259-66, p. 264: 'the most appropriate analysis of the relations of legal systems is pluralistic rather than monistic, and interactive rather than hierarchical'.

161 N. Walker, 'Constitutionalism and Pluralism in Global Context' in M. Avbelj and J. Komárek (eds), Constitutional Pluralism in the European Union and Beyond (Hart Publishing 2012), pp. 17-18.

162 See Jaklič (n 13), especially pp. 165-73.

163 BVerfGE 89, 155 (Maastricht). See Baquero Cruz (n 23).
} 
point in this story has been that such judgments, critical as they might have been, have not actually threatened the functioning of EU law nor the existence of the Union. However, exactly this has now happened with the ruling of the German court that outright declared the answer it had received from the CJEU to its preliminary reference ultra vires, and thereby also the actions of the ECB. The Federal Constitutional Court's PSPP judgment affirms the topicality and necessity of the approach adopted in this book: to study the theory of constitutional pluralism in light of the events of the euro crisis. Furthermore, the judgment also highlights the practical relevance of the argument made herein as well as the criticism presented towards constitutional pluralism as a normative theory of European constitutionalism. 